\title{
Karakteristik Bahasa Anak Sekolah Dasar Muhammadiyah II Denpasar: Kajian Morfologi
}

\author{
Putri Dwi Ardhanariswari $^{1^{*}}$, I Ketut Darma Laksana ${ }^{2}$, Ni Putu N. Widarsini ${ }^{3}$ \\ ${ }^{\left[{ }^{[123}\right]}$ Program Studi Sastra Indonesia, Fakultas Ilmu Budaya, Universitas Udayana \\ [ardhanariswari95@gmail.com], ${ }^{2}$ [darmalaksana27@yahoo.com], \\ 3 [n_widarsini@unud.ac.id] \\ *Corresponding Author
}

\begin{abstract}
This research titled "The Language Characteristic of Student at Elementary School Muhammadiyah II Denpasar: Morphology Study". The purpose of this research is to know the form and forming of word that was mastered by students of elementary school Muhammadiyah II Denpasar and the factors that influence of mastering the language. The process of collecting the data uses seeing method. The process of analysis the data uses apportion, qualitative, and quantitative method. Besides, in process of the result uses informal and formal method. The result of this research was found the form and the forming of word that was already mastered by students of elementary school Muhammadiyah II Denpasar. The form includes lexicon category, lexicon form, and boarding lexicon. In lexicon category found (1) 812 nominal, (2) 553 verbal, (3) 162 adjectives, and (4) 67 numeralias. In lexicon form found (1) 1.180 single words and (2) 1.038 complex words. Besides, the process of forming word found (1) affix includes (a) prefix $\{$ ber-\}, \{meng-\}, \{di-\}, \{per-\}, \{peng-\}, \{se-\}, \{ter-\}; (b) sufixs $\{$-an\}, \{-i\}, \{-kan\}, $\{-n y a\}$; (c) konfixs $\{k e-\ldots-a n\},\{b e r-\ldots-a n\},\{$ per-...-an\}, \{se-...-nya\}, \{peng-...-an\}; and (d) simulfixs \{meng-...-kan\}, \{di-...-kan\}, \{memper-...-kan\}, \{memper-...-i\}; (2) reduplication includes morfemis reduplication and fonologis reduplication; (3) composition includes nominal composition and verbal composition; and (4) abbrevation includes abbreviation, piece, acronym, and contraction. The factors that influence the process of mastering the language are internal and external factor. Internal factor includes ages, connection ability, and health. Besides, the external factor includes influent of formal and informal environment of the student.
\end{abstract}

Keywords: form, forming word, students language

\begin{abstract}
Abstrak
Penelitian ini berjudul "Karakteristik Bahasa Anak Sekolah Dasar Muhammadiyah II Denpasar: Kajian Morfologi". Tujuan penelitian ini adalah untuk mengetahui bentuk dan pembentukan kata yang dikuasai oleh anak Sekolah Dasar Muhammadiyah II Denpasar serta faktor-faktor yang memengaruhi proses penguasaan bahasa tersebut. Pada proses pengumpulan data digunakan metode simak. Pada proses analisis data digunakan metode agih, metode analisis kualitatif, dan metode analisis kuantitatif. Sementara itu, pada proses penyajian hasil analisis data digunakan metode informal dan formal. Hasil penelitian ini adalah ditemukan bentuk dan pembentukan kata yang sudah dikuasai oleh siswa-siswi Sekolah Dasar Muhammadiyah II Denpasar. Bentuk meliputi
\end{abstract}


kategori leksikon, bentuk leksikon, dan keluasan leksikon. Pada kategori leksikon, ditemukan (1) 812 nomina, (2) 553 verba, (3) 162 adjektiva, dan (4) 67 numeralia. Pada bentuk leksikon, ditemukan (1) 1.180 kata tunggal dan (2) 1.038 kata kompleks. Sementara itu, proses pembentukan kata yang ditemukan adalah (1) afiksasi meliputi (a) prefiks $\{$ ber- $\},\{$ meng- $\},\{$ di- $\},\{$ per- $\},\{$ peng- $\},\{$ se- $\},\{$ ter- $\}$; (b) sufiks $\{-a n\},\{-i\},\{-$ $k a n\},\{-n y a\}$; (c) konfiks $\{k e-\ldots-a n\},\{$ ber-...-an $\},\{$ per-...-an $\},\{$ se-...-nya $\},\{$ peng-...an\}; dan (d) simulfiks $\{$ meng-...-kan $\},\{d i-\ldots-k a n\},\{$ memper-...-kan $\},\{$ memper-...-i $\}$; (2) reduplikasi meliputi reduplikasi morfemis dan reduplikasi fonologis; (3) komposisi meliputi komposisi nominal dan komposisi verbal; serta (4) abreviasi meliputi singkatan, penggalan, akronim, dan kontraksi. Faktor-faktor yang memengaruhi proses penguasaan bahasa tersebut ialah faktor internal dan faktor eksternal. Faktor internal meliputi usia, daya tangkap, dan kesehatan anak, sedangkan faktor eksternal meliputi pengaruh lingkungan formal dan pengaruh lingkungan informal di sekitar anak.

Kata kunci: bentuk, pembentukan kata, bahasa anak

\section{Latar Belakang}

Bahasa adalah satu sistem yang bersifat sistematis dan sistemis. Bahasa tidak merupakan satu sistem tunggal, tetapi dibangun oleh sejumlah subsistem, yaitu subsistem fonologi, sintaksis, dan leksikon (Chaer, 2015:30). Kemampuan berbahasa seseorang sangat dipengaruhi oleh beberapa faktor. Salah satu di antaranya ialah factor usia. Kemampuan berbahasa pada orang dewasa sangat berbeda dengan kemampuan berbahasa anak. Pada umumnya proses berbahasa anak-anak cenderung sangat sederhana, mereka terkadang belum tepat dalam penggunaan kata dan kalimat untuk mengungkapkan sesuatu. Karakteristik bahasa anak dapat dilihat dari kemampuan mereka dalam penguasaan sistem-sistem bahasa yang meliputi sistem fonologi, morfologi, sintaksis, semantik, dan pragmatik. Berdasarkan penjelasan tersebut, penulis tertarik untuk melakukan penelitian mengenai karakteristik bahasa anak sekolah dasar dilihat dari segi morfologis karena menurut Zuhdi dan Budiasih (dalam BPSDMPK DAN PMP, 2018:19), anakanak mempelajari morfem mula-mula bersifat hafalan kemudian diikuti dengan membuat simpulan secara kasar tentang bentuk dan makna morfem dan akhirnya anak membuat sebuah kaidah. Berdasarkan kerumitan proses afiksasi, perkembangan morfologis anak dapat diduga sebagai berikut:

(1) anak kelas awal sekolah dasar telah menggunakan kata berprefiks dan bersufiks, seperti melempar dan makanan;

(2) anak kelas menengah sekolah dasar telah menggunakan kata berimbuhan simulfiks/konfiks sederhana, seperti menjauhi dan disatukan; dan

(3) anak kelas atas sekolah dasar telah menggunakan kata berimbuhan konfiks yang kompleks, seperti diperdengarkan dan memberlakukan dalam bahasa lisan atau tulisan. Dengan demikian, penelitian ini terfokus pada segi bentuk dan pembentukan kata yang digunakan oleh siswa-siswi kelas lima Sekolah Dasar Muhammadiyah II Denpasar.

\section{Rumusan Masalah}

Berdasarkan latar belakang di atas, dapat dirumuskan permasalahan dalam penelitian ini. Adapun masalah yang dikaji adalah sebagai berikut. 
1) Bentuk dan proses pembentukan kata apa sajakah yang dikuasai anak Sekolah Dasar Muhammadiyah II Denpasar?

2) Faktor-faktor apa sajakah yang memengaruhi proses penguasaan bahasa anak Sekolah Dasar Muhammadiyah II Denpasar dari segi bentuk dan pembentukan kata?

\section{Tujuan Penelitian}

Secara umum penelitian ini bertujuan untuk memperoleh informasi tentang penguasaan bahasa anak ditinjau dari segi morfologis dan faktor-faktor yang memengaruhi proses penguasaan tersebut. Secara khusus penelitian ini memiliki dua tujuan sebagai berikut.

1) Mengetahui bentuk dan pembentukan kata yang dikuasai oleh anak Sekolah Dasar Muhammadiyah II Denpasar.

2) Mengetahui faktor-faktor yang memengaruhi proses penguasaan bahasa anak Sekolah Dasar Muhammadiyah II Denpasar dilihat dari segi bentuk dan pembentukan kata.

\section{Metode Penelitian}

Metode dan teknik pengumpulan data yang digunakan dalam penelitian ini adalah metode simak dengan teknik sadap, teknik catat, teknik simak libat cakap, dan simak bebas libat cakap. Pada tahap analisis data digunakan metode agih dengan teknik dasar bagi unsur langsung (BUL), kemudian dilanjutkan dengan teknik lesap, teknik ulang, dan teknik ganti. Selain menggunakan metode agih, penelitian ini juga menggunakan metode kuantitatif dan metode kualitatif. Hasil analisis data disajikan dengan metode informal dan metode formal.

\section{Hasil dan Pembahasan}

5.1 Bentuk Kata dan Pembentukan Kata yang Dikuasai oleh SiswaSiswi Muhammadiyah II Denpasar

\subsubsection{Kategori Leksikon}

Pada karangan siswa-siswi Sekolah Dasar Muhammadiyah II Denpasar ditemukan pemakaian kata yang berkategori nomina, numeralia, verba, dan adjektiva. Kategori leksikon tersebut dapat dilihat pada tabel berikut.

\begin{tabular}{llrr}
\hline No. & Kata & $\begin{array}{c}\text { Jumlah } \\
\text { Kata }\end{array}$ & $\begin{array}{c}\text { Persentase } \\
(\%)\end{array}$ \\
\hline 1. & Nomina & 812 & $51 \%$ \\
2. & Numeralia & 67 & $4,2 \%$ \\
3. & Verba & 553 & $34,7 \%$ \\
4. & Adjektiva & 162 & $10,1 \%$ \\
& Jumlah & $\mathbf{1 . 5 9 4}$ & $\mathbf{1 0 0 \%}$ \\
\hline
\end{tabular}

\subsubsection{Bentuk Leksikon}

Pada karangan siswa-siswi Sekolah Dasar Muhammadiyah II Denpasar ditemukan pemakaian kata berupa kata tunggal dan kata kompleks. Bentuk leksikon tersebut dapat dilihat pada tabel berikut.

\begin{tabular}{llcc}
\hline No. & Kata & $\begin{array}{c}\text { Jumlah } \\
\text { Kata }\end{array}$ & $\begin{array}{c}\text { Persentase } \\
(\%)\end{array}$ \\
\hline 1. & $\begin{array}{l}\text { Kata } \\
\text { Tunggal }\end{array}$ & 1.180 & $53,2 \%$ \\
2. & $\begin{array}{l}\text { Kata } \\
\text { Kompleks }\end{array}$ & 1.038 & $46,8 \%$ \\
& Jumlah & $\mathbf{2 . 2 1 8}$ & $\mathbf{1 0 0 \%}$ \\
\hline
\end{tabular}

\subsubsection{Keluasan Leksikon}

Pada karangan yang terkumpul diketahui bahwa siswa-siswi Sekolah Dasar Muhammadiyah II Denpasar sudah mampu menguasai leksikon-leksikon mengenai lingkungan di sekitar mereka, mata pencaharian, dan anggota tubuh. 


\begin{tabular}{|c|c|c|}
\hline Lingkungan & $\begin{array}{c}\text { Mata } \\
\text { Pencaharian }\end{array}$ & $\begin{array}{c}\text { Anggota } \\
\text { Tubuh }\end{array}$ \\
\hline Meja & dokter & kepala \\
\hline kursi & koki & mata \\
\hline sawah & peternak & lidah \\
\hline ladang & dosen & hati \\
\hline
\end{tabular}

\subsubsection{Proses Pembentukan Kata}

\begin{tabular}{|c|c|c|c|c|c|}
\hline \multirow[b]{2}{*}{$\dot{0}$} & \multirow{2}{*}{ 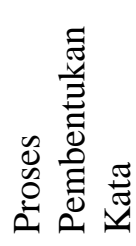 } & \multicolumn{2}{|c|}{ Kelas 5A } & \multicolumn{2}{|c|}{ Kelas 5C } \\
\hline & & 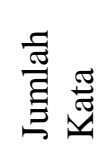 & 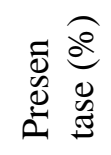 & $\begin{array}{l}\text { 点 } \\
\text { 营 }\end{array}$ & 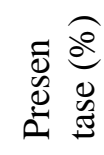 \\
\hline 1. & $\begin{array}{l}\text { Afiksas } \\
\text { i }\end{array}$ & 381 & $\begin{array}{l}81,8 \\
\%\end{array}$ & 494 & $\begin{array}{l}85,8 \\
\%\end{array}$ \\
\hline 2. & $\begin{array}{l}\text { Redupl } \\
\text { ikasi }\end{array}$ & 59 & $\begin{array}{l}12,6 \\
\%\end{array}$ & 45 & $\begin{array}{l}7,9 \\
\%\end{array}$ \\
\hline 3. & $\begin{array}{l}\text { Kompo } \\
\text { sisi }\end{array}$ & 13 & $\begin{array}{l}2,8 \\
\%\end{array}$ & 23 & 3,9 \\
\hline 4. & $\begin{array}{l}\text { Abrevi } \\
\text { asi }\end{array}$ & 13 & $\begin{array}{l}2,8 \\
\%\end{array}$ & 14 & $\begin{array}{l}2,4 \\
\%\end{array}$ \\
\hline & & 466 & $\begin{array}{l}100 \\
\%\end{array}$ & 576 & $\begin{array}{l}100 \\
\%\end{array}$ \\
\hline
\end{tabular}

Berdasarkan tabel di atas dapat dilihat bahwa proses pembentukan kata yang dikuasai oleh siswa-siswi meliputi afiksasi, reduplikasi, komposisi, dan abreviasi. Proses pembentukan kata yang paling banyak ditemukan, yaitu proses afiksasi. Pada tabel di atas juga dapat dilihat bahwa siswa-siswi yang berada di kelas 5C lebih banyak menghasilkan kata-kata yang mengalami proses morfologis daripada siswa-siswi yang berada di kelas 5A. Siswa-siswi kelas 5C mampu menghasilkan kata sebanyak 576 kata, sedangkan siswa-siswi kelas 5A hanya 466 kata.

\subsubsection{Afiksasi}

Menurut Ramlan (1983:47-49), afiksasi merupakan proses pembubuhan afiks pada suatu satuan, baik berupa bentuk tunggal maupun bentuk kompleks, untuk membentuk kata.

\section{1) Prefiks}

Prefiks yang ditemukan pada karangan siswa-siswi Sekolah Dasar Muhammadiyah II Denpasar adalah $\{$ ber, meng-, di-, ke-, per-, peng-, se-, ter- $\}$.

Contoh:

$\{$ ber -$\}+$ kerja $\rightarrow /$ bekerja/ (P5A18)

Prefiks $\{$ ber- $\}$ memiliki fungsi sebagai pembentuk kata kerja, seperti data berikut.

(a) Dia bekerja di kapal (P5A18).

Prefiks $\{$ ber- $\}$ juga memiliki makna 'melakukan pekerjaan mengenai diri sendiri', seperti data berikut.

(a) Setelah membantu ibu saya belajar (K5C7). Makna belajar ialah 'melakukan pekerjaan terhadap diri sendiri, yaitu belajar'.

\section{2) Sufiks}

Sufiks yang ditemukan pada karangan siswa-siswi Sekolah Dasar Muhammadiyah II Denpasar adalah $\{-a n$, $-i$, -kan, -nya .

Contoh:

suka $+\{-i\} \rightarrow$ /sukai/ (L5C3)

Prefiks $\{-i\}$ memiliki fungsi sebagai pembentuk kata kerja, seperti data berikut.

(a) Semua rumah yang aku datangi selalu memberikanku uang (L5C4).

Prefiks $\{-i\}$ sebagai pembentuk kata kerja mempunyai makna '...di', '...ke', '...kepada', '...dari', seperti data berikut. (a) Semua rumah yang aku datangi selalu memberikanku uang (L5C4). Makna datangi ialah 'dari semua rumah tetangga yang aku datangi selalu memberikanku uang'. 


\section{3) Konfiks}

Konfiks yang ditemukan pada karangan siswa-siswi Sekolah Dasar Muhammadiyah II Denpasar adalah $\{k e$ ...-an, ber-...-an, per-...-an, se-...-nya, peng-...-an\}.

Contoh:

$\{$ peng- $\}+$ lihat $+\{-a n\} \rightarrow$ penglihatan (O5A4)

Konfiks $\quad\{$ peng-...-an $\}$ memiliki fungsi sebagai pembentuk kata benda, seperti data berikut.

(a) Bila mata kita mengalami masalah tentu saja penglihatan akan bermasalah juga (O5A4).

Konfiks $\quad\{$ peng-...-an $\}$ memiliki makna 'proses, perbuatan, atau cara meng-...', seperti data berikut.

(a) Pada saat Idhul Adha di rumah saya ada pemotongan kambing (L5A5). Makna pemotongan ialah 'proses, perbuatan memotong kambing'.

\section{4) Simulfiks}

Simulfiks yang ditemukan pada karangan siswa-siswi Sekolah Dasar Muhammadiyah II Denpasar adalah \{meng-...-kan, di-...-kan, memper-...kan, memper-...-i\}.

Contoh:

$\{$ meng- $\}+$ nyala $+\{-k a n\} \rightarrow$ menyalakan (K5A8)

Simulfiks \{meng-...-kan\} memiliki fungsi sebagai pembentuk kata kerja, seperti data berikut.

(a) Sesampai di kelas saya menyalakan lampu dan $\mathrm{AC}$ (K5A8).

Simulfiks $\{$ meng-...-kan $\}$ memiliki makna 'menyebabkan terjadinya suatu proses', seperti data berikut. (a) Sesampai di kelas saya menyalakan lampu dan AC (K5A8). Makna menyalakanialah 'menyebabkan terjadinya proses (nyala)'

\subsubsection{Reduplikasi}

Reduplikasi adalah proses morfologis yang mengubah sebuah leksem menjadi kata setelah mengalami proses morfologis reduplikasi (Arifin dan Junaiyah, 2009:11). Reduplikasi yang ditemukan pada karangan siswa-siswi adalah sebagai berikut.

\section{1) Reduplikasi Morfemis}

Reduplikasi morfemis yang ditemukan pada karangan siswa-siswi Sekolah Dasar Muhammadiyah II Denpasar, meliputi reduplikasi akar dan reduplikasi berafiks.

Reduplikasi akar yang ditemukan meliputi reduplikasi utuh (dwilingga), reduplikasi sebagian (dwipurwa), dan reduplikasi berubah bunyi (dwilingga salin suara).

Contoh:

(a) siap-siap (K5C7)

(b) lelaki (P5C3)

(c) siswa-siswi (K5A19)

Reduplikasi berafiks yang ditemukan meliputi akar berprefiks \{ber-, ter-, se-\}, akar bersufiks $\{-a n,-n y a\}$, dan akar berkonfiks $\{k e-\ldots-a n$, ber-...-an, se-...nya\}.

Contoh:
(a) berjalan-jalan (L5A7)
(b) sayur-sayuran (LN5C28)
(c) setinggi-tingginya (P5A9)

\section{2) Reduplikasi Fonologis}

Reduplikasi fonologi berlangsung terhadap dasar yang bukan akar atau terhadap bentuk yang statusnya lebih tinggi daripada akar. Status bentuk yang diulang tidak jelas dan reduplikasi ini 
tidak menghasilkan makna gramatikal, tetapi menghasilkan makna leksikal (Chaer, 2008:179).

Contoh:

(a) paru-paru (O5A20)

Bentuk paru-paru sudah jelas sebagai bentuk ulang dan dasar yang diulang pun jelas, yaitu paru. Namun, hasil reduplikasinya tidak menghasilkan makna gramatikal, melainkan hanya menghasilkan makna leksikal, yaitu 'organ tubuh yang berupa sepasang kantong berbentuk bulat toraks, terdapat dalam rongga dada, dan berfungsi sebagai alat pernapasan'.

\subsubsection{Komposisi}

Komposisi atau pemajemukan adalah proses morfologis yang mengubah gabungan leksem menjadi satu kata, yaitu kata majemuk (Arifin dan Junaiyah, 2009:12). Komposisi yang ditemukan pada karangan siswa-siswi adalah sebagai berikut.

\section{1) Komposisi Nominal}

(a) nomina + nomina, seperti terdapat pada data berikut.

(1) bulu mata (O5C21)

(b) nomina + verba, seperti terdapat pada data berikut.

(1) meja makan (K5C12)

(c) nomina + adjektiva, seperti terdapat pada data berikut.

(1) orang tua (KG5A10)

Komposisi verbal yang ditemukan pada karangan siswa-siswi memiliki makna gramatikal, idiomatik, dan metaforis. Komposisi nominal bermakna gramatikal, misalnya kamar tidur (K5C21). Komposisi nominal bermakna idiomatik, misalnya matahari (LN5C4). Sementara itu, komposisi nominal bermakna metaforis, misalnya kepala desa (LN5C15).

\section{2) Komposisi Verbal}

(a) verba + verba, seperti terdapat pada data berikut.

(1) buka puasa (L5A9)

(b) verba + nomina, seperti terdapat pada data berikut.

(1) makan malam (K5C2)

Komposisi verbal yang ditemukan pada karangan siswa-siswi hanya memiliki makna gramatikal. Komposisi verbal bermakna gramatikal, misalnya tidur siang (K5C7) dan makan malam (K5C2).

\subsubsection{Abreviasi}

Menurut Kridalaksana (1989:159163), abreviasi atau yang biasanya disebut pemendekan adalah proses penanggalan satu atau beberapa bagian leksem atau kombinasi leksem menjadi bentuk baru yang berstatus kata. Hasil proses abreviasi ini ialah kependekan. Kependekan iui, terbagi atas beberapa jenis, yaitu (1) singkatan, (2) penggalan, (3) akronim, (4) kontraksi, dan (5) lambang huruf.

\section{1) Singkatan}

Singkatan merupakan salah satu proses pemendekan yang berupa huruf atau gabungan huruf, baik yang dieja huruf demi huruf maupun tidak dieja huruf demi huruf, seperti pada data berikut.

(a) THR (Tunjuagan Hari Raya) (L5A7)

(b) IPA (Ilmu Pengetahuan Alam) (OA18)

\section{2) Penggalan}

Penggalan merupakan salah satu proses pemendekan yang mengekalkan salah satu bagian leksem, seperti pada data berikut.
(a) $\mathrm{Bu}(\mathrm{K} 5 \mathrm{C} 27)$ 
(b) Pak (K5A10)

\section{3) Akronim}

Akronim merupakan proses pemendekan yang menggabungkan huruf atau suku kata atau bagian lain yang ditulis dan dilafalkan sebagai sebuah kata sedikit banyak memenuhi kaidah fonotaktik Indonesia, seperti pada data berikut.
(a) Unud (Universitas Udayana) (KG5A25)
(b) Unram (Universitas Mataram) (L5C13)

\section{4) Kontraksi}

Kontraksi merupakan proses pemendekan yang meringkaskan leksem dasar atau gabungan leksem. Kontraksi hanya ditemukan pada data berikut.

(a) ortu (orang tua) (KG5A18)

\subsection{Faktor-Faktor yang Memengaruhi Proses Penguasaan Bahasa Anak}

Proses penguasaan bahasa anak tentunya sangat dipengaruhi oleh faktorfaktor tertentu. Faktor-faktor tersebut dapat meliputi faktor internal dan eksternal anak yang bersangkutan. Faktor-faktor yang memengaruhi penguasaan bahasa siswa-siswi Sekolah Dasar Muhammadiyah II dijelaskan sebagai berikut.

\subsubsection{Faktor Internal}

Perbedaan usia di antara siswasiswi Sekolah Dasar Muhammadiyah II Denpasar tidak memengaruhi kemampuan berbahasa anak. Rata-rata usia siswa-siswi Sekolah Dasar Muhammadiyah II Denpasar ialah 10 dan 11 tahun. Namun, pada karangan yang telah dikumpulkan dapat dibuktikan bahwa siswa-siswi berusia 10 tahun sudah menguasai pemakaian kata, seperti pemakaian nomina, verba, adjektiva, numeralia, dan proses morfologis. (a) Keluargaku berasal dari Jawa Tengah (KG5C2)

(b) Ayahku berasal dari Prancis (KG5A20)

\begin{tabular}{lll}
\hline \multicolumn{1}{c}{ Nama } & \multicolumn{1}{c}{ Usia } & \multicolumn{1}{c}{ Kode Data } \\
\hline Anisa & 10 tahun & KG5C2 \\
Arya & 11 tahun & KG5A20 \\
\hline
\end{tabular}

Selain faktor usia, faktor internal lainnya yang perlu diperhatikan adalah proses daya tangkap anak dan kesehatan anak yang bersangkutan. Dalam penelitian ini ditemukan salah seorang siswi yang memiliki daya tangkap dan kesehatan yang kurang baik sehingga saat diberikan tugas untuk mengarang terkadang siswi tersebut mengalami kesulitan dalam membuat karangan. Terkadang siswi tersebut membuat karangan dengan melihat karangan yang telah ada di dalam buku pelajaran dan menulisnya kembali sehingga tema yang diangkat siswa tersebut dalam karangannya sangat berbeda dengan tema karangan yang telah ditentukan.

\subsubsection{Faktor Eksternal}

\subsubsection{Pengaruh Lingkungan Formal}

Menurut Krashen (dalam Chaer, 2009:125), lingkungan formal bahasa memiliki ciri (1) bersifat artifisial, (2) merupakan bagian dari keseluruhan pengajaran bahasa di sekolah atau di kelas, dan (3) di dalamnya pembelajar diarahkan untuk melakukan aktivitas bahasa yang menampilkan kaidah-kaidah bahasa yang telah dipelajari kemudian guru akan mengoreksi kesalahan yang dilakukan oleh pembelajar.

Sekolah Muhammadiyah II Denpasar merupakan sekolah Islam sehingga kosakata bahasa Arab sering digunakan, baik dalam bentuk sapaan maupun hal lainnya. Kosakata bahasa Arab yang muncul pada karangan siswa-siswi, misalnya tahfidz 'hafalan Alquran' 
(K5A25, K5C16). Namun, dalam bahasa Indonesia kata tahfidz penulisannya adalah tahfiz 'hafalan Alquran'.

\subsubsection{Pengaruh Lingkungan Informal}

Chaer (2009:260) berpendapat bahwa lingkungan informal bersifat alami dan tidak dibuat-buat. Lingkungan informal tersebut meliputi bahasa yang digunakan oleh teman-teman sebaya, orang tua, pengasuh, bahasa yang digunakan anggota kelompok pembelajar, bahasa yang digunakan media massa, bahasa guru, baik di kelas maupun di luar kelas. Lingkungan tersebut sangat berpengaruh terhadap hasil belajar bahasa bagi pembelajar.

$$
\text { Pada karangan siswa-siswi }
$$

Sekolah Dasar Muhammadiyah II Denpasar ditemukan beberapa kosakata ragam informal, seperti kata ngobrol (L5A1), salim (L5A1), dan rame (L5C12). Selain itu, dalam karangan siswa-siswi Sekolah Dasar Muhammadiyah II Denpasar juga ditemukan penggunaan sufiks bahasa Bali, yaitu sufiks -in. Sufiks -in tersebut ditemukan pada kata mainin (K5C12), ngambilin (K5A2), dan nglanjutin (K5A2). Munculnya kosakata bahasa ragam informal tersebut disebabkan oleh orang-orang di sekitar anak yang bersangkutan sering menggunakan bahasa ragam informal ketika berinteraksi dengan anak tersebut. Penggunaan bahasa ragam informal di dalam keluarga juga memberikan dampak besar terhadap proses penguasaan bahasa anak.

\section{Simpulan}

Berdasarkan hasil analisis data mengenai bentuk dan pembentukan kata pada karangan siswa-siswi dapat disimpulkan sebagai berikut.

1. Berdasarkan kategori leksikon, ditemukan 812 nomina (51\%), 67 numeralia (4,2\%), 553 verba $(34,7$ $\%)$, dan 162 adjektiva $(10,1 \%)$ pada karangan siswa-siswi.

2. Berdasarkan bentuk leksikon, pemakaian kata yang ditemukan pada karangan siswa-siswi, meliputi kata tunggal dan kata kompleks. Seluruh pemakaian kata pada karangan siswa-siswi berjumlah 2.390 kata. Dari keseluruhan kata tersebut, ditemukan 1.038 kata kompleks $(43,4 \%)$ dan 1.180 kata tunggal $(49,4 \%)$.

3. Proses morfologis yang ditemukan pada karangan siswa-siswi, meliputi afiksasi, reduplikasi, komposisi, dan abreviasi. Pemakaian afiks dilihat dari bentuk, fungsi, dan makna terdiri atas (1) prefiks $\{$ ber- $\}$, \{meng- $\}, \quad\{d i-\}, \quad\{$ per- $\}, \quad\{$ peng- $\}$, $\{$ se- $\},\{$ ter- $\}$; (2) sufiks $\{-a n\},\{-i\}$, $\{-k a n\},\{-n y a\} ;(3)$ konfiks $\{k e-\ldots-$ an $\},\{$ ber-...-an $\},\{$ per-...-an $\},\{$ se...-nya $\}, \quad\{$ peng-...-an $\}$; dan (4) simulfiks $\quad\{$ meng-...-kan $\}, \quad\{d i-\ldots-$ kan\}, \{memper-...-kan\}, \{memper...-i\}, dan \{meng-...-i\}. Reduplikasi yang ditemukan pada karangan siswa-siswi terdiri atas reduplikasi morfemis (reduplikasi akar dan reduplikasi berafiks) dan reduplikasi fonologis. Komposisi yang ditemukan pada karangan siswasiswi terdiri atas komposisi nominal dan komposisi verbal. Sementara itu, abreviasi yang ditemukan pada karangan siswa-siswi terdiri atas singkatan, penggalan, akronim, dan kontraksi.

4. Faktor-faktor yang memengaruhi proses penguasaan bahasa terdiri atas faktor internal dan faktor eksternal. Faktor internal meliputi usia, daya tangkap, dan kesehatan anak, sedangkan faktor eksternal meliputi pengaruh lingkungan formal dan 
informal di sekitar anak yang bersangkutan.

\section{Daftar Pustaka}

Arifin, E. Zaenal dan Junaiyah H.M. 2009. Morfologi Bentuk, Makna, dan Fungsi. Jakarta: Grasindo.

BPSDMPK dan PMP. 2012. Karakteristik Perkembangan Bahasa Anak. Jakarta: Pusat Pengembangan Profesi Pendidik.

Chaer, Abdul. 2008. Morfologi Bahasa Indonesia (Pendekatan Proses). Jakarta: Rineka Cipta.

Chaer, Abdul. 2015. Psikolinguistik Kajian Teoretik. Jakarta: Rineka Cipta.

Kridalaksana, Harimurti. 1989. Pembentukan Kata dalam Bahasa Indonesia. Jakarta: PT Gramedia.

Ramlan, M. 1983. Morfologi Suatu Tinjauan Deskriptif. Yogyakarta: CV Karyono. 